\title{
Separation/Enrichment of Copper and Silver Using Titanium Dioxide Nanoparticles Coated with Poly-Thiophene and Their Analysis by Flame Atomic Absorption Spectrophotometry
}

\author{
Mohammad Behbahani ${ }^{1}$, Meysam Babapour ${ }^{1}$, Mostafa M. Amini ${ }^{1}$, Omid Sadeghi ${ }^{2}$, \\ Akbar Bagheri $^{*}$, Mani Salarian ${ }^{1}$, Banafsheh Rafiee ${ }^{1}$ \\ ${ }^{1}$ Department of Chemistry, Shahid Beheshti University, Tehran, Iran \\ ${ }^{2}$ Department of Chemistry, Islamic Azad University, Shahr-e-Rey Branch, Tehran, Iran \\ Email: *me-bagheri@sbu.ac.ir
}

Received December 9, 2012; revised January 8, 2013; accepted January 15, 2013

\begin{abstract}
We report on the use of titanium dioxide nanoparticles (NPs) coated with poly-thiophene for the preconcentration of copper and silver ions. The NPs were prepared by first modifying the surface of $\mathrm{TiO}_{2} \mathrm{NPs}$ with vinyl groups and then copolymerizing them with vinyl thiophen. The resulting $\mathrm{TiO}_{2}$-polythiophene core-shell NPs were characterized by thermogravimetry, differential thermal analysis, scanning electron microscopy, Fourier transform infrared spectrometry and X-ray diffraction. The experimental conditions such as $\mathrm{pH}$ value, adsorption and desorption time, type, concentration and volume of the eluent, break through volume, and effect of potentially interfering ions were optimized. The ions were then desorbed with hydrochloric acid and determined by FAAS. The limits of detection are 0.4 and $1.2 \mu \mathrm{g} \cdot \mathrm{L}^{-1}$ for $\mathrm{Cu}(\mathrm{II})$ and $\mathrm{Ag}(\mathrm{I})$, respectively, and recoveries and precisions are $>98.0 \%$ and $<4 \%$.
\end{abstract}

Keywords: Novel Poly-Thiophene- $\mathrm{TiO}_{2}$ Nanoparticles; Copper; Silver; Flame Atomic Absorption Spectrophotometry

\section{Introduction}

Heavy metals contamination is an important topic due to its various effects on human health and environment, and furthermore, exposure to certain heavy metals at trace amounts can entail irrecoverable and severe effects [1-4]. In addition, the presence of heavy metals in water has been a major concern for many years due to their toxicity, which endangers the aquatic-life. The sources of heavy metals pollution are mainly industries such as metal cleaning, mining activities, metal finishing, and etc $[5,6]$.

Although copper is an indispensable element, which is needed by the human body, it can cause serious difficultties at excess amounts. Actually, water consumption with the concentration of copper at more than the permissible level of $2 \mathrm{mg} / \mathrm{L}$ [7] during years can lead to dangerous problems such as stomach and intestinal distress, liver and kidney damage, and anaemia [8]. High levels of copper may result in severe toxicity of living organisms through inhibition of metabolic reactions. The two diseases which are heavily related to copper metabolism in humans are Menkes disease and Wilson disease [9-11]. Despite its toxicity, copper plays an essential role in bio-

\footnotetext{
"Corresponding author.
}

logical processes like blood formation and function of many important enzymes; furthermore, copper can be classified as a biogenic element due to its vital role in photosynthesis, metabolism of nitrogen compounds or regulation of RNA and DNA transcription process $[12,13]$. Moreover, trace levels of copper is essential as co-factors of enzymatic reactions [14].

Silver has many antimicrobial properties since ancient Romans used silver coins for treatment of drinking water; furthermore, the increased antibiotic resistance of many bacteria has led to a renewed interest in silver as a biocide agent [15]. Antimicrobial coatings of colloidal silver have various applications such as deodorizing shoe inserts, washing machines, and wound dressings $[15,16]$. Although silver has many applications and advantages, its high levels can be toxic to human cells. For instance, it can slow the healing of the wound. In addition, silver has other problems, including argyria which is a condition characterized by a permanent blue-gray discoloration of the skin [17]. In respect to electrical and thermal conductivity and ductility, silver has been widely used in different fields such as aerospace, communications, chemical industry, medical equipment, electroplating, photographic materials, and electronic industries. However, 
silver resources in the world are extremely scarce and mainly along with lead, copper and antimony deposits, and due to the low concentrations, it is necessary to preconcentrate and separate silver ions before recovery [18,19].

Analysis of trace heavy metals is difficult because of their very low concentrations in samples and high complexity of sample matrices. Therefore, preliminary preconcentration and matrix removal steps are highly needed to ensure the accuracy and precision of the analytical results [20]. Various preconcentration techniques such as solvent extraction, coprecipitation, cloud point extraction, ion-exchange, solid phase extraction and electroanalytical techniques [21-25] have been developed for various environmental samples.

Solid phase extraction (SPE) is an efficient separation-preconcentration technique for heavy metals since it has many important advantages, including simplicity, flexibility, economic, rapid, and higher enrichment factors, absence of emulsion, low cost because of lower consumption of reagents, and more importantly it is environment friendly. Various SPE materials have been successfully used for preconcentration and separation of heavy-metal ions at trace levels [26-30]. The basic principle of SPE is the transfer of the analyte from the aqueous phase to bind to active sites of the vicinal solid phase. It has several advantages over other techniques, includeing stability and reusability of the solid phase, high preconcentration factors, easy separation and enrichment under dynamic conditions, no need for consumption of organic solvents, which may be toxic and hazardous and finally, minimum costs because of low consumption of reagents [31].

Titanium dioxide nanoparticles have been widely used in commercial products such as sunscreens [32] and photocatalysts [33]; they have also been introduced as sorbents for removal of contaminants [34-36]. It is reported that $\mathrm{TiO}_{2}$ nanotubes have larger surface area compared to titanium dioxide powder itself, and contain more ion-exchangeable $\mathrm{OH}$ groups in the interlayer and surface $[37,38] . \mathrm{TiO}_{2}$ nanotubes has attracted great attentions in analytical chemistry because of its high chemical stability, durability, corrosion resistance, non-toxicity, and cost effectiveness. Furthermore, micro-scaled $\mathrm{TiO}_{2}$ has been used as stationary phase in HPLC applications [39] as well as a solid phase extraction adsorbent for the preconcentration of metal ions [40-42] and selective extraction of phosphates, phospholipids and phosphopeptides [43]. Moreover, $\mathrm{TiO}_{2}$ nanotubes were demonstrated to be excellent adsorbents of inorganic cations and anions as well as organic compounds [44].

In the present study, $\mathrm{TiO}_{2}$ nanoparticels were modified with poly-thiophene and used as a solid phase for simultaneous ultra-trace separation and determination of silver and copper ions in several water samples. Various factors affecting the adsorption and desorption steps for the mentioned ions were investigated and optimized. The studied factors include effects of $\mathrm{pH}$, adsorption and desorption time, type, concentration, and volume of the eluent for elution of silver and copper ions, break through volume and effect of coexisting ions on separation and determination of these heavy metals. Poly-thiophene modified titanium dioxide was successfully applied for solid phase extraction of silver and copper in water samples and flame atomic absorption spectrometry (FAAS) was used to measure the above ions in solutions. Finally, the mentioned adsorbent was validated using thermogravimetry analysis (TGA), differential thermal analysis (DTA), scanning electron microscopy (SEM), Fourier transform infrared spectroscopy (FT-IR), and X-ray diffraction (XRD).

\section{Materials and Methods}

\subsection{Reagents}

$\mathrm{TiO}_{2}$ nanoparticles with $10-15 \mathrm{~nm}$ in diameter were purchased from Neutrino Company (Iran-Tehran). AIBN (2,2'-Azobisisobutyronitrile) was purchased from Acros Organics Company (New Jersey, USA). Vinyl-triethoxysilane, 3-vinyl thiophene and the other reagents used were of analytical grade and purchased from Merck Company (Darmstadt, Germany). Double-distilled water from a Milli-Q purification system (Millipore, Bedford, MA, USA) was used for the preparation of solutions. Stock solutions of $\mathrm{Cu}(\mathrm{II}), \mathrm{Cd}(\mathrm{II}), \mathrm{Mn}(\mathrm{II}), \mathrm{Ni}(\mathrm{II}), \mathrm{Cr}(\mathrm{III})$, $\mathrm{Al}(\mathrm{III}), \mathrm{Fe}(\mathrm{II}), \mathrm{Pb}$ (II), $\mathrm{Mg}$ (II), Ca(II), Cs(I), $\mathrm{Na}(\mathrm{I}), \mathrm{Ag}(\mathrm{I})$, and $\mathrm{K}(\mathrm{I})$ were prepared from Titrisol solutions (Merck, Darmstadt, Germany). Working solutions were prepared by dilution of stock solutions $\left(1000 \mathrm{mg} \cdot \mathrm{L}^{-1}\right)$ with deionized water. $\mathrm{HCl}, \mathrm{HNO}_{3}$, and $\mathrm{CH}_{3} \mathrm{COOH}$ as the elution solvents were purchased from Merck Company (Whitehouse Station, NJ, USA).

\subsection{Instrumentation}

Copper and silver concentration was determined by an AA-680 Shimadzu (Kyoto, Japan) flame atomic absorption spectrometer (FAAS) in an air-acetylene flame, according to the user's manual, provided by the manufacturer. Copper and silver hollow cathode lamps (HCL) were used as the radiation source with wavelengths of 324.8 and $328.1 \mathrm{~nm}$, respectively. All pH measurements were recorded at $25^{\circ} \mathrm{C} \pm 1^{\circ} \mathrm{C}$ with a digital WTW Metrohm 827 Ion Analyzer (Herisau, Switzerland), equipped with a combined glass-calomel electrode. X-ray diffraction patterns were obtained on a STOE diffractometer with $\mathrm{Cu} \mathrm{K} \alpha$ radiation. The Elemental analysis was performed with a Thermo Finnigan Flash-2000 microanalyzer (Italy). IR spectra were recorded by BOMEM/MB series Spectrometer. Thermal gravimetric and differential 
thermal analysis (TG/DTA) was carried out on a Bahr STA-503 instrument under air atmosphere. SEM micrograph was recorded on Vega-TeScan microscope.

\subsection{Synthesis of Vinyl Functionalized $\mathrm{TiO}_{2}$ Nanoparticles}

For synthesis of vinyl functionalized $\mathrm{TiO}_{2}$ nano-particles, $1.0 \mathrm{~g}$ of $\mathrm{TiO}_{2}$ nanoparticles was suspended in $50 \mathrm{~mL}$ of toluene, afterward $2 \mathrm{~mL}$ of vinyl-triethoxysilane was added to the solution, and the mixture was stirred at room temperature for $48 \mathrm{~h}$. The white solid was separated by filtration, washed with ethanol and dried at room temperature. The vinyl functionalization was confirmed by IR spectroscopy and elemental analysis. Elemental analysis of this nanocomposite shows that the vinyl concentration is approximately $0.74 \mathrm{mmol}$ per gram of $\mathrm{TiO}_{2}$ nanoparticles $(\mathrm{C}=2.66 \%, \mathrm{H}=0.38 \%)$.

\subsection{Preparation of Poly-Thiophene Coated $\mathrm{TiO}_{2}$ Nanoparticles}

The coating of polymer on the surface of $\mathrm{TiO}_{2}$ nanoparticles was carried out by simple polymerization of vinyl groups on the surface of $\mathrm{TiO}_{2}$ nanoparticles and 3-vinyl thiophene. In this approach, $0.1 \mathrm{~g}$ vinyl- $\mathrm{TiO}_{2}$ nanoparticles was suspended in $100 \mathrm{~mL}$ of methanol containing $100 \mu \mathrm{L}$ of 3-vinyl thiophene and then $0.2 \mathrm{~g}$ of AIBN was added to the mixture and was heated to $60^{\circ} \mathrm{C}$. After $24 \mathrm{~h}$ the composite was separated by centrifuge, washed with methanol and dried in the vacuum at $80^{\circ} \mathrm{C}$. The formation of poly-thiophene on the surface of $\mathrm{TiO}_{2}$ nanoparticle was confirmed by IR spectroscopy, X-ray powder diffraction, elemental, and thermal analysis. A schematic diagram for synthesis of this composite is shown in Figure 1.

\subsection{Real Samples Pretreatment}

Standard materials with a certified amount of copper and silver ions were used for method validation. These samples were digested in an $8 \mathrm{~mL}$ mixture of $5 \%$ aqua regia with the assistance of a microwave digestion system. Digestion was carried out for $2 \mathrm{~min}$ at $250 \mathrm{~W}, 2$ min at 0 $\mathrm{W}, 6 \mathrm{~min}$ at $250 \mathrm{~W}, 5 \mathrm{~min}$ at $400 \mathrm{~W}$ and $8 \mathrm{~min}$ at $550 \mathrm{~W}$, and the mixture was then vented for $8 \mathrm{~min}$. The residue from this digestion was then diluted with deionized water.

The water samples, including distilled water, tap water (Tehran, Iran), river waters obtained from Siahrood river and Derka river (Ghaemshahr, Iran) and sea water (Caspian Sea, Sari, Iran) were collected in cleaned polyethylene bottles and filtered through a $0.45 \mathrm{~mm}$ pore size nylon filter (Millipore) immediately after sampling. The amounts of copper and silver ions were then successfully determined by the present method.

\section{Results and Discussion}

\subsection{Sorbent Characterization}

The polymerization reaction of vinyl functionalized $\mathrm{TiO}_{2}$ nanoparticles with 3-vinyl thiophene in presence of AIBN as the initiator leads to formation of this sorbent. A schematic diagram for synthesis of this composite is shown in Figure 1. The formation of poly-thiophene on the surface of $\mathrm{TiO}_{2}$ nanoparticles was confirmed by IR spectroscopy, X-ray powder diffraction, elemental and Thermal analysis. The presence of peaks at $3038(\mathrm{CH}$, aromatic), 2979 (CH, aliphatic), $1559(\mathrm{C}=\mathrm{C}$, aromatic $)$ in IR spectrum confirm the presence of thiophene in this sorbent. The amount of grafted pyridine was calculated by elemental analysis. According to the elemental analysis results, approximately $1.88 \mathrm{mmol}$ thiophene is grafted on each gram of $\mathrm{TiO}_{2}$ nanoparticles. In order to confirm $\mathrm{TiO}_{2}$ nanoparticles remain intact after functionalization (no decomposition), XRD pattern of final product was recorded. Comparing to the reference pattern (JCPDS file, No. 86-0147) the results show that the structure of $\mathrm{TiO}_{2}$ nanoparticles remained intact after coating with the polymer (Figure 2). In order to investigate the size and morphology of sorbent, SEM micrograph of the sorbent was recorded. As it can be seen in Figure 3, spherical nanoparticles with approximately $40-60 \mathrm{~nm}$ in diameter were obtained. Finally, the thermal stability of this sorbent was investigated by TG-DTA analysis. According to these results, this sorbent is stable up to $270^{\circ} \mathrm{C}$ (Figure 4). Furthermore, according to these results, approximately $24 \%$ of this material is consisting of poly-thiophene polymer.

\subsection{Sorption Step}

\subsubsection{Effect of Solution's pH}

Among the tested variables, $\mathrm{pH}$ was found to be the most critical parameter for adsorption of metals on the polythiophene- $\mathrm{TiO}_{2}$ nanoparticles [45]. To evaluate the effect of $\mathrm{pH}$ on the extraction efficiency, the $\mathrm{pH}$ of $25 \mathrm{~mL}$ of sample solutions containing $2 \mathrm{mg} \cdot \mathrm{L}^{-1}$ of copper and silver ions was adjusted in the range of 2 to 9 . The data graphed as a function of $\mathrm{pH}$ for poly-thiophene- $\mathrm{TiO}_{2}$ nanoparticles is shown in Figure 5. As can be seen in Figure 5, the quantitative retention of copper and silver ions on the poly-thiophene- $\mathrm{TiO}_{2}$ nanoparticles was obtained in the $\mathrm{pH}$ of 7 . Thus, all samples were adjusted to pH 7 for further studies.

\subsubsection{Equilibrium Sorption Time}

In a typical uptake kinetics test, $15 \mathrm{mg}$ of the sorbent was added to $25 \mathrm{~mL}$ of $2 \mathrm{mg} \cdot \mathrm{L}^{-1} \mathrm{Cu}$ (II) and $\mathrm{Ag}$ (I) aqueous solution at $\mathrm{pH}$ 7. The resulting suspension was stirred in different times (i.e., from 2 to $10 \mathrm{~min}$ ) under magnetic stirring. According to the results in Table 1, an optimum 


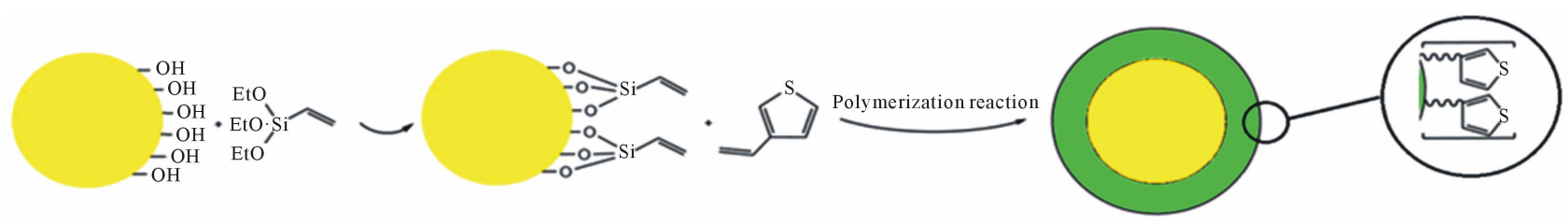

Figure 1. Schematic illustration of poly-thiophene coated $\mathrm{TiO}_{2}$ nanoparticles.

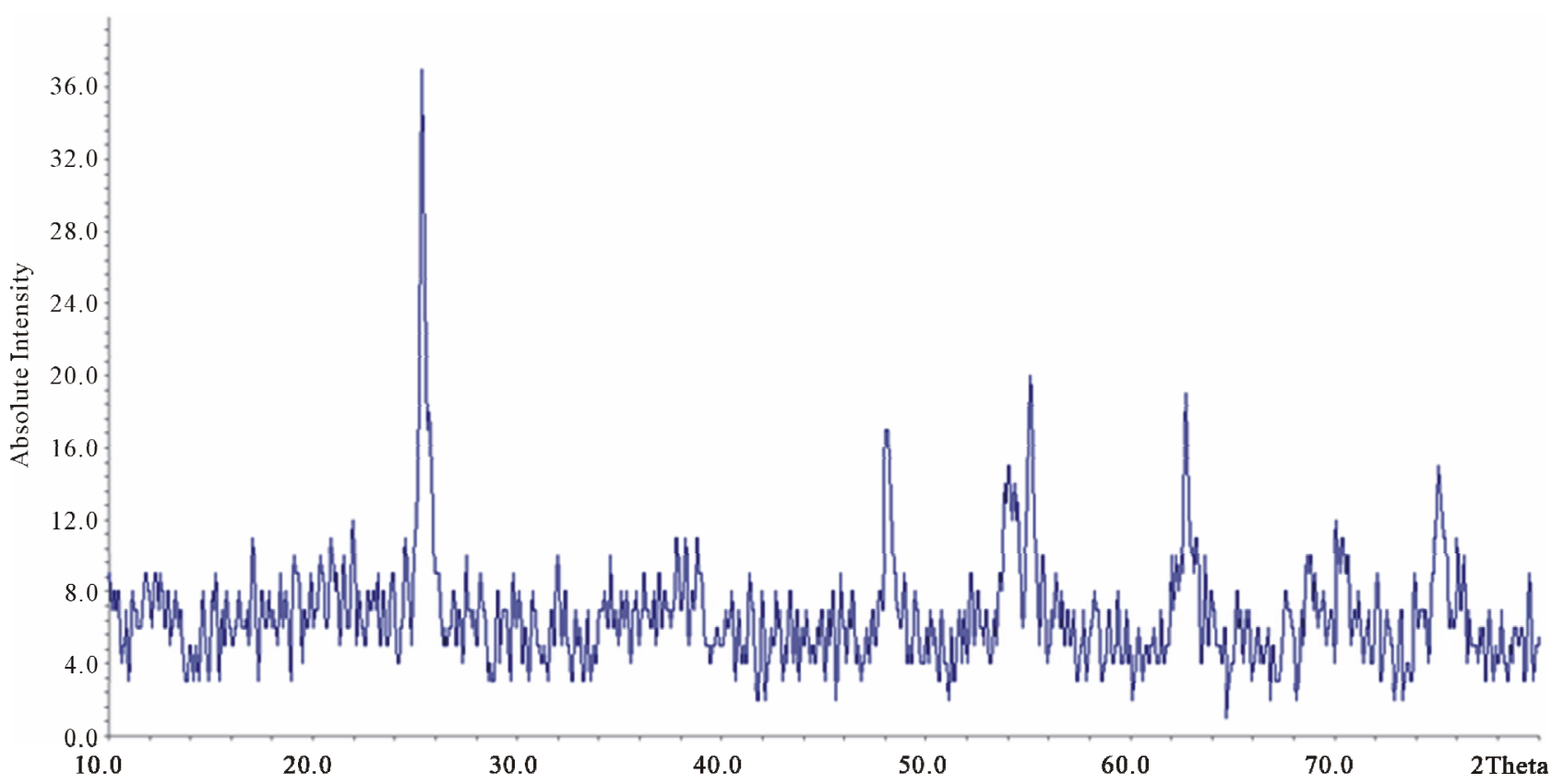

Figure 2. XRD pattern of poly-thiophene coated $\mathrm{TiO}_{2}$ nanoparticles.

Table 1. Influence of sorption and desorption Times on retention and recovery of copper and silver poly-thiophene coated $\mathrm{TiO}_{2}$ nanoparticles.

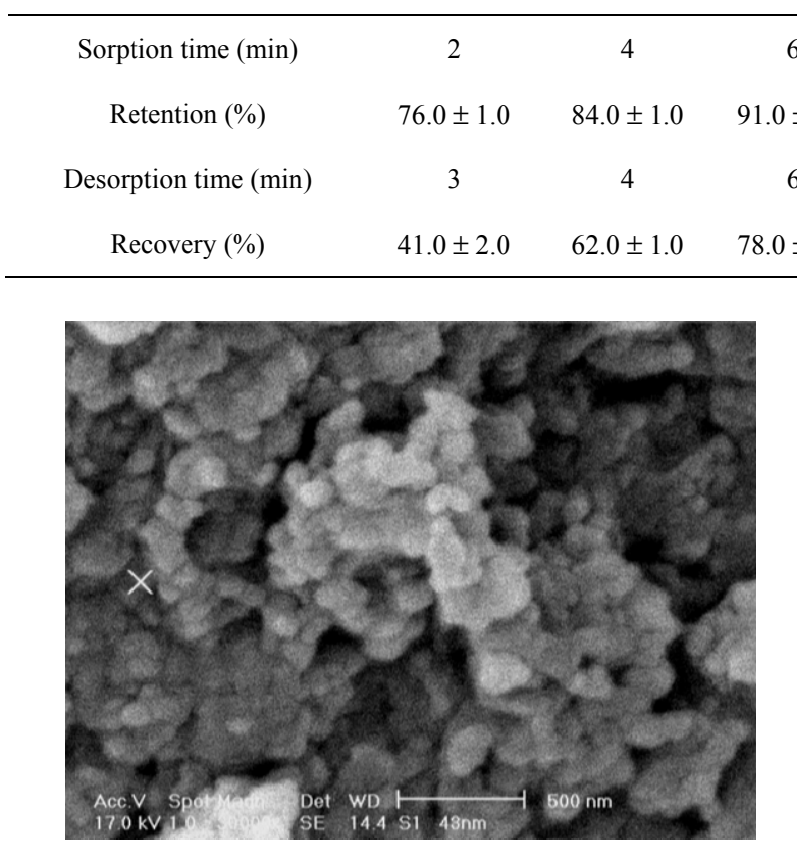

Figure 3. SEM micrograph of poly-thiophene coated $\mathrm{TiO}_{2}$ nanoparticles.

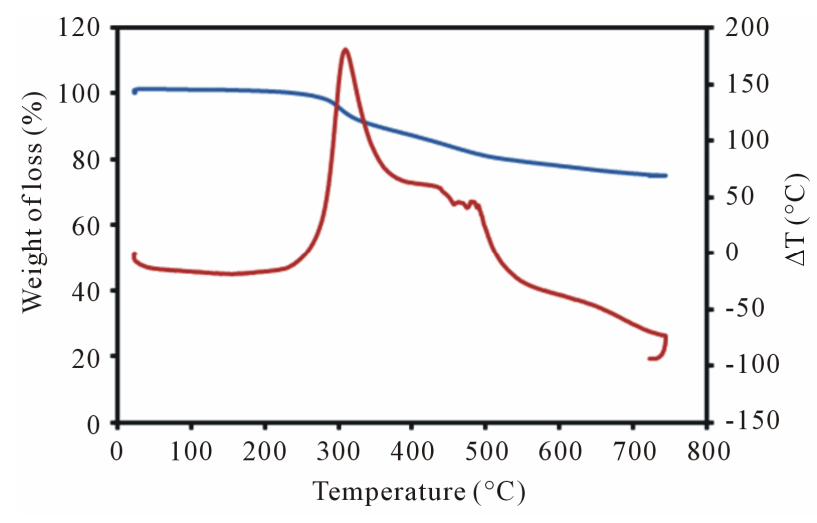

Figure 4. TGA and DTA poly-thiophene coated $\mathrm{TiO}_{2}$ nanoparticles. 


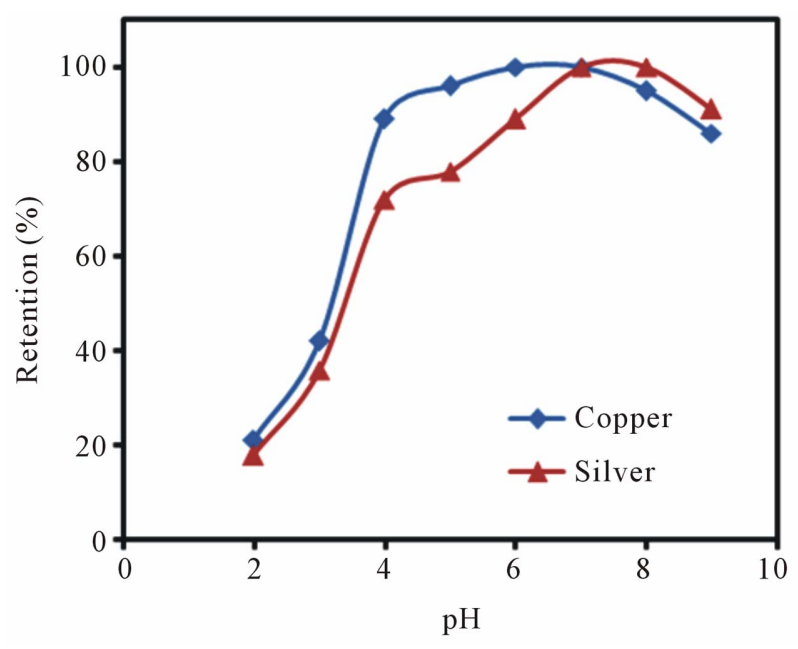

Figure 5. Effect of sample pH on the retention of $\mathrm{Cu}$ (II) and $\mathrm{Ag}(\mathrm{I})$ ions on poly-thiophene coated $\mathrm{TiO}_{2}$ nanoparticles.

equilibration time of 7 min was obtained for quantitative extraction of the analytes from solution into the solid phase.

\subsubsection{Effect of Amount of Nanoparticles}

The influence of the mass of nanoparticles (5 - $20 \mathrm{mg}$ ) used for quantitative extraction of copper and silver was investigated. $15 \mathrm{mg}$ of the nanoparticles was obtained as the optimum amount of adsorbent. Subsequent experiments were performed for $15 \mathrm{mg}$ modified nanoparticles.

\subsection{Desorption Step}

\subsubsection{Effect of Type, Concentration and Volume of Eluent}

Various solvents such as $\mathrm{HNO}_{3}, \mathrm{HCl}$, and acetic acid were tested to obtain the best eluent for the removal of $\mathrm{Cu}(\mathrm{II})$ and $\operatorname{Ag}(\mathrm{I})$ ions [46]. According to experiments, $\mathrm{HCl}$ showed the best recovery among other solvents. The effects of eluent's concentration and volume on the recovery of copper and silver ions were also studied. As shown in Table 2, best quantitative recovery can be obtained with $5 \mathrm{~mL}$ of $\mathrm{HCl}\left(2 \mathrm{~mol} \cdot \mathrm{L}^{-1}\right)$. After the sorption of $\mathrm{Cu}(\mathrm{II})$ and $\mathrm{Ag}(\mathrm{I})$ ions by the nanoparticles, the nanoparticles were separated from the solution through filtration. Then, poly-thiophene- $\mathrm{TiO}_{2}$ nanoparticles were first washed with distilled water in order to remove nonspecifically retained matrices from the nanoparticles. Then, modified $\mathrm{TiO}_{2}$ nanoparticles were dried, and the extracted copper and silver ions were eluted by $\mathrm{HCl}$ through batch experiments.

\subsubsection{Desorption Time}

In order to investigate the optimum desorption time, various times were examined in the range of 2 to $15 \mathrm{~min}$, while other parameters were kept in optimum conditions.
As shown in Table 1, extraction recovery was increased up to $10 \mathrm{~min}$ and it was constant in longer times. Therefore, 10 minutes can be the best quantitative time for the elution of metal ions from the poly-thiophene- $\mathrm{TiO}_{2}$ nanoparticles.

\subsection{Effect of Sample Volume}

In the analysis of real samples, the sample volume is one of the important parameters influencing the preconcentration factor. Therefore, the effect of sample volume on quantitative adsorption of $\mathrm{Cu}(\mathrm{II})$ and $\mathrm{Ag}(\mathrm{I})$ ions was investigated. For this purpose, $15 \mathrm{mg}$ of nanoparticles was suspended in different sample volumes $(25,50,100,250$, $500,750,900,1000,1250,1400$ and $1500 \mathrm{~mL}$ ), and the total amount of loaded $\mathrm{Cu}(\mathrm{II})$ and $\mathrm{Ag}(\mathrm{I})$ was kept constant in $0.1 \mathrm{mg}$. All solutions were extracted under the optimum conditions by the proposed method. The results in Figure 6 demonstrated that the simultaneous quantitative recovery of copper and silver ions on poly-thiophene- $\mathrm{TiO}_{2}$ nanoparticles can be obtained for sample volume up to $900 \mathrm{~mL}$.

\subsection{Evaluation of Adsorption Capacity}

In this work, Langmuir isotherms were used to measure the adsorption of copper and silver ions onto poly-thiophene- $\mathrm{TiO}_{2}$ surface. The Langmuir adsorption model is a theoretical equation and applicable to homogeneous binding sites and assumes that the molecules are adsorbed at a fixed number of well-defined sites, each of which can only hold one molecule. These sites are also assumed to

Table 2. The effect of type, concentration, and volume of the eluent on extraction efficiency.

\begin{tabular}{|c|c|c|c|}
\hline Eluent & $\begin{array}{c}\text { Concentration } \\
\left(\mathrm{mol} \cdot \mathrm{L}^{-1}\right)\end{array}$ & Volume (mL) & $\mathrm{R}^{\mathrm{a}} \% \pm \mathrm{S}^{\mathrm{b}}$ \\
\hline & & & $\mathrm{Ag}$ \\
\hline $\mathrm{HCl}$ & 3 & 10 & $99.0 \pm 1.099 .0 \pm 1.0$ \\
\hline $\mathrm{HCl}: \mathrm{CH}_{3} \mathrm{COOH}$ & $1: 1$ & 10 & $71.0 \pm 2.076 .0 \pm 2.0$ \\
\hline $\mathrm{HNO}_{3}: \mathrm{CH}_{3} \mathrm{COOH}$ & $1: 1$ & 10 & $68.0 \pm 1.064 .0 \pm 2.0$ \\
\hline $\mathrm{CH}_{3} \mathrm{COOH}$ & 3 & 10 & $52.0 \pm 1.054 .0 \pm 1.5$ \\
\hline $\mathrm{HNO}_{3}$ & 3 & 10 & $93.0 \pm 1.091 .0 \pm 2.0$ \\
\hline $\mathrm{HCl}$ & 2 & 10 & $99.0 \pm 1.099 .0 \pm 1.0$ \\
\hline $\mathrm{HCl}$ & 1 & 10 & $90.0 \pm 1.088 .0 \pm 1.0$ \\
\hline $\mathrm{HCl}$ & 2 & 7.5 & $99.0 \pm 1.099 .0 \pm 1.0$ \\
\hline $\mathrm{HCl}$ & 2 & 5 & $99.0 \pm 1.099 .0 \pm 1.0$ \\
\hline $\mathrm{HCl}$ & 2 & 2.5 & $76.0 \pm 1.073 .0 \pm 1.0$ \\
\hline
\end{tabular}

${ }^{\mathrm{a}}$ Recovery; ${ }^{\mathrm{b}}$ Standard deviation. 


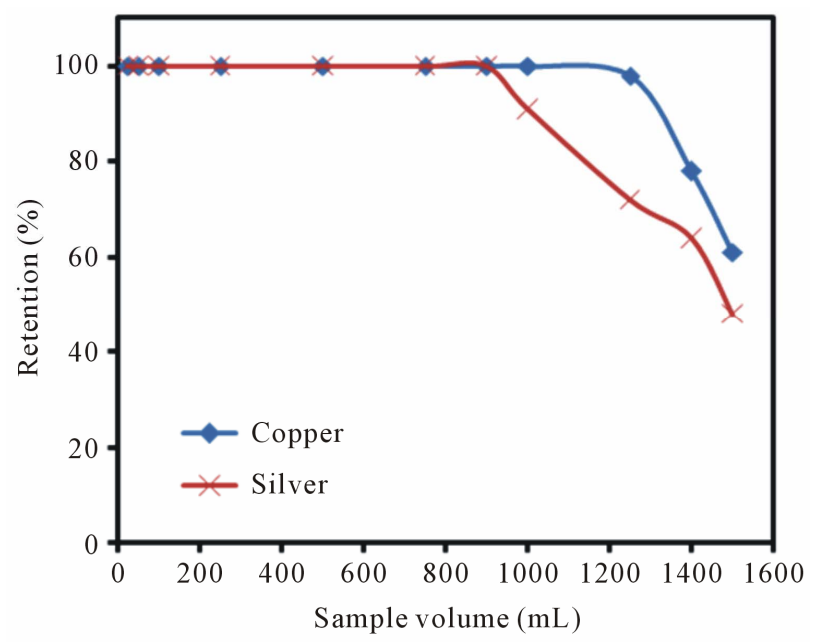

Figure 6. Effect of sample solution volume on extraction recovery of copper and silver ions on poly-thiophene coated $\mathrm{TiO}_{2}$ nanoparticles.

be energetically equivalent and distant to each other; therefore, there are no interactions between molecules adsorbed on adjacent sites. The amount of $\mathrm{Cu}(\mathrm{II})$ and $\mathrm{Ag}(\mathrm{I})$ bound by the nanoparticles was calculated according to the following formula:

$$
Q=\frac{(C 0-C) V}{1000 W}
$$

where $Q$ is the amount of adsorbed $\mathrm{Cu}(\mathrm{II})$ and $\mathrm{Ag}(\mathrm{I})$ $\left(\mathrm{mg} \cdot \mathrm{g}^{-1}\right) ; \mathrm{C} 0$ and $C$ are the initial and final concentrations of $\mathrm{Cu}(\mathrm{II})$ and $\mathrm{Ag}(\mathrm{I})\left(\mathrm{mg} \cdot \mathrm{L}^{-1}\right)$, respectively; $\mathrm{V}$ is the volume of mixture $(\mathrm{mL})$; and $\mathrm{W}$ is the amount of nanoparticles $(\mathrm{g})$.

The Langmuir adsorption isotherm is expressed by Equation (6).

$$
Q=\frac{Q_{\max } b C e}{1+b C e}
$$

where $Q$ is the amount of adsorbed $\mathrm{Cu}(\mathrm{II})$ and $\mathrm{Ag}(\mathrm{I})$ ions on the poly-thiophene- $\mathrm{TiO}_{2}$ nanoparticles at equilibrium $\left(\mathrm{mg} \cdot \mathrm{g}^{-1}\right), \mathrm{Ce}$ is the equilibrium concentration of $\mathrm{Cu}(\mathrm{II})$ and $\operatorname{Ag}(\mathrm{I})$ ions in solution $\left(\mathrm{mg} \cdot \mathrm{L}^{-1}\right)$ and $Q_{\max }$ and $\mathrm{b}$ are Langmuir constants related to the maximum adsorption capacity and energy of adsorption, respectively. The Langmuir equation can be linearized in a normal form for the determination of Langmuir constants:

$$
\frac{1}{Q}=\left(\frac{1}{Q_{\max }}\right)+\frac{1}{b Q_{\max } C e}
$$

Langmuir equations for copper and silver at $\mathrm{pH} 7$ for $25 \mathrm{~mL}$ of sample volume and $15 \mathrm{mg}$ of the sorbent are as follows:

$$
\mathrm{Y}=0.123 \mathrm{X}+0.024\left(\mathrm{R}^{2}=0.996\right) \text { Langmuir equations }
$$
for copper;
$\mathrm{Y}=0.158 \mathrm{X}+0.032\left(\mathrm{R}^{2}=0.995\right)$ Langmuir equations for silver.

According to the relations above, adsorption capacities for $\mathrm{Cu}(\mathrm{II})$ and $\mathrm{Ag}(\mathrm{I})$ were calculated to be $41.66 \mathrm{mg} \cdot \mathrm{g}^{-1}$ and $31.25 \mathrm{mg} \cdot \mathrm{g}^{-1}$, respectively.

\subsection{Effect of Interfering Ions}

In order to investigate the effect of various cations existed in natural samples; elements that are known as alkaline, alkaline earth, and transition metals were added to $100 \mathrm{~mL}$ of solution containing $0.01 \mathrm{mg}$ copper and silver ions. The degree of tolerance for some alkaline, alkaline earth and transition metal ions is presented in Table 3. From the tolerance data, it can be found that the other ions have no significant effects on preconcentration of copper and silver ions at $\mathrm{pH}$ of 7.0.

\subsection{Statistical and Calibration Parameters}

Under optimum conditions that have been described, this SPE method showed a linear calibration curve within concentration ranging from 1 to $100 \mu \mathrm{g} \cdot \mathrm{L}^{-1}$ for copper and 3 to $120 \mu \mathrm{g} \cdot \mathrm{L}^{-1}$ for silver. The least square equation at above dynamic linear range for copper and silver was as follows:

$$
\begin{aligned}
& A=0.018 C_{\mathrm{Cu}}\left(\mu \mathrm{g} \cdot \mathrm{L}^{-1}\right)+0.041,\left(R^{2}=0.997\right) \\
& A=0.011 C_{\mathrm{Ag}}\left(\mu \mathrm{g} \cdot \mathrm{L}^{-1}\right)+0.003,\left(R^{2}=0.997\right)
\end{aligned}
$$

The limits of detection, defined as $\mathrm{C}_{\mathrm{LOD}}=3 \mathrm{~S}_{\mathrm{b}} / \mathrm{m}$, where $S_{b}$ is the standard deviation of 6 replicate blank

Table 3. The tolerance limit of various ions on the determination of copper and silver ions.

\begin{tabular}{cccc}
\hline \multirow{2}{*}{ Foreign ion } & \multirow{2}{*}{$\begin{array}{c}\text { Tolerable Concentration } \\
\text { Ratio X/Cu and } \mathrm{Ag}\end{array}$} & \multicolumn{2}{c}{$\mathrm{R}^{\mathrm{a} \%} \pm \mathrm{S}^{\mathrm{b}}$} \\
\cline { 3 - 4 } & 10,000 & $99.0 \pm 1.0$ & $99.0 \pm 2.0$ \\
$\mathrm{~K}^{+}$ & 10,000 & $99.0 \pm 2.0$ & $99.0 \pm 2.0$ \\
$\mathrm{Na}^{+}$ & 1000 & $99.0 \pm 2.0$ & $98.0 \pm 2.0$ \\
$\mathrm{Cs}^{+}$ & 600 & $97.0 \pm 1.0$ & $98.0 \pm 1.0$ \\
$\mathrm{Ca}^{2+}$ & 700 & $98.0 \pm 1.0$ & $98.0 \pm 1.0$ \\
$\mathrm{Mg}^{2+}$ & 800 & $96.0 \pm 1.0$ & $98.0 \pm 1.0$ \\
$\mathrm{Al}^{+3}$ & 700 & $97.0 \pm 1.0$ & $96.0 \pm 1.0$ \\
$\mathrm{Cr}^{3+}$ & 100 & $96.0 \pm 2.0$ & $95.0 \pm 1.0$ \\
$\mathrm{~Pb}^{2+}$ & 500 & $96.0 \pm 2.0$ & $97.0 \pm 2.0$ \\
$\mathrm{Fe}^{2+}$ & 200 & $96.0 \pm 2.0$ & $97.0 \pm 1.0$ \\
$\mathrm{Ni}^{2+}$ & 300 & $96.0 \pm 2.0$ & $97.0 \pm 1.0$ \\
$\mathrm{Mn}^{2+}$ & 400 & $98.0 \pm 1.0$ & $96.0 \pm 1.0$ \\
$\mathrm{Cd}^{2+}$ & & & \\
\hline
\end{tabular}

${ }^{\mathrm{a}}$ Recovery; ${ }^{\mathrm{b}}$ Standard deviation. 
signals and $\mathrm{m}$ is the slope of the linear section of the calibration curve after preconcentration, for a sample volume of $500 \mathrm{~mL}$, was found to be $0.4 \mathrm{ng} \cdot \mathrm{mL}^{-1}$ for copper and $1.2 \mathrm{ng} \cdot \mathrm{mL}^{-1}$ for silver ions. In order to calculate the blank value, $15 \mathrm{mg}$ of the modified nanoparticles was added to $500 \mathrm{~mL}$ of blank solution and the solution was stirred for $7 \mathrm{~min}$. Then, the solution was filtered and the remaining nanoparticles was added to $5 \mathrm{~mL}$ of $\mathrm{HCl}(2$ $\mathrm{mol} \cdot \mathrm{L}^{-1}$ ) as the elution solvent and, again the solution was stirred for $10 \mathrm{~min}$. Finally, the solution was filtered and determined by FAAS. The relative standard deviation for six separate batch experiments with $15 \mathrm{mg}$ of sorbent for determination of $8 \mu \mathrm{g}$ of $\mathrm{Cu}(\mathrm{II})$ and $\mathrm{Ag}(\mathrm{I})$ in $500 \mathrm{~mL}$ of water was $3.1 \%$ and $2.2 \%$, respectively.

\subsection{Real Sample and Certified Reference Material Analysis}

The applicability of the sorbent for preconcentration and determination of trace levels of $\mathrm{Cu}(\mathrm{II})$ and $\mathrm{Ag}(\mathrm{I})$ was tested using different water samples. For the preconcentration procedure, $\mathrm{pH}$ of $500 \mathrm{~mL}$ of real samples was adjusted to 7.0 and spiked with copper and silver ions and was used in batch method. The concentration of sorbed $\mathrm{Cu}(\mathrm{II})$ and $\mathrm{Ag}(\mathrm{I})$ ions were determined based on a triplicate analysis (Table 4). It was found that the quantitative extraction of copper and silver ions was performed successfully by the sorbent even in the presence of various diverse ions.

Certified reference material (ore polymetallic gold zidarovo-PMZrZ (206 BG 326)) was used for the validation of the proposed method. As it can be seen in Table 4, good correlation was achieved between estimated content by the present method and reference materials. Therefore, poly-thiophene- $\mathrm{TiO}_{2}$ nanotubes can be used as a reliable solid-phase for extraction and determination of copper and silver ions in water samples.

\section{Conclusion}

In this study, a simple, efficient and reliable method was set up to determine the trace amounts of copper and silver in the aqueous solution using modified titanium oxide nanoparticles as SPE sorbent coupled with FAAS. According to our experimental results, $\mathrm{TiO}_{2}$ nanoparticles modified with poly-thiophene have good analytical potential for the extraction of silver and copper ions from real environmental water samples. Taking into account the simplicity and low cost of poly-thiophene- $\mathrm{TiO}_{2}$ nanoparticles, as well as the good extraction efficiencies, these modified nanoparticles have a great potential of becoming a cost effective and useful extraction tool in analytical methods. The precision and accuracy of the proposed method were satisfactory and percentage of $\mathrm{Ag}(\mathrm{I})$ and $\mathrm{Cu}(\mathrm{II})$ removal from solution is close to $100 \%$ at $\mathrm{pH}$ of 7 .

Table 4. The determination of copper and silver in various real samples and certified reference material.

\begin{tabular}{|c|c|c|c|c|c|}
\hline Sample & Element & Real sample $\left(\mathrm{ng} \cdot \mathrm{mL}^{-1}\right)$ & Added $\left(\mathrm{ng} \cdot \mathrm{mL}^{-1}\right)$ & Found (ng $\cdot \mathrm{mL}^{-1}$ ) & Recovery (\%) \\
\hline \multirow{3}{*}{ Distilled water } & $\mathrm{Cu}$ & N.D. & 5.00 & 4.96 & 99.2 \\
\hline & & & & & \\
\hline & $\mathrm{Ag}$ & N.D. & 5.00 & 4.99 & 99.8 \\
\hline \multirow{3}{*}{ Tap water } & $\mathrm{Cu}$ & 10.10 & 5.00 & 14.91 & 98.7 \\
\hline & & & & & \\
\hline & $\mathrm{Ag}$ & N.D & 5.00 & 4.91 & 98.2 \\
\hline \multirow{3}{*}{ Siahrood river water } & $\mathrm{Cu}$ & 54.20 & 5.00 & 59.30 & 100.1 \\
\hline & & & & & \\
\hline & $\mathrm{Ag}$ & 9.10 & 5.00 & 14.02 & 99.4 \\
\hline \multirow{3}{*}{ Derka river water } & $\mathrm{Cu}$ & 37.20 & 5.00 & 42.10 & 99.7 \\
\hline & & & & & \\
\hline & $\mathrm{Ag}$ & 7.92 & 5.00 & 12.83 & 99.3 \\
\hline \multirow{3}{*}{ Caspian sea water } & $\mathrm{Cu}$ & 78.10 & 5.00 & 82.95 & 99.8 \\
\hline & & & & & \\
\hline & $\mathrm{Ag}$ & 13.20 & 5.00 & 18.12 & 99.5 \\
\hline \multirow{3}{*}{ Ore polymetallic gold zidarovo-PMZrZ (206 BG 326) } & $\mathrm{Cu}$ & 510 & - & 502 & 98.4 \\
\hline & & & & & \\
\hline & $\mathrm{Ag}$ & 17,200 & - & 17,150 & 99.7 \\
\hline
\end{tabular}




\section{Acknowledgements}

We gratefully acknowledge financial support from the Research Council of Shahid Beheshti University.

\section{REFERENCES}

[1] M. Jamil, M. S. Zia and M. Qasim, "Contamination of Agro-Ecosystem and Human Health Hazards from Wastewater Used for Irrigation," Journal of the Chemical Society of Pakistan, Vol. 32, No. 3, 2010, pp. 370-378.

[2] S. Khan, Q. Cao, Y. M. Zheng, Y. Z. Huang and Y. G. Zhu, "Health Risks of Heavy Metals in Contaminated Soils and Food Crops Irrigated with Wastewater in Beijing," Environmental Pollution, Vol. 152, No. 3, 2008, pp. 686-692. doi:10.1016/j.envpol.2007.06.056

[3] S. O. Lesmana, N. Febriana, F. E. Soetaredjo, J. Sunarso and S. Ismadji, "Studies on Potential Applications of Biomass for the Separation of Heavy Metals from Water and Wastewater," Biochemical Engineering Journal, Vol. 44, No. 1, 2009, pp. 19-41. doi:10.1016/j.bej.2008.12.009

[4] B. Debelius, J. M. Forja, A. D. Valls and L. M. Lubian, "Toxicity and Bioaccumulation of Copper and Lead in Five Marine Microalgae," Ecotoxicology and Environmental Safety, Vol. 72, No. 5, 2009, pp. 1503-1513. doi:10.1016/j.ecoenv.2009.04.006

[5] B. G. Wei and L. S. Yang, "A Review of Heavy Metal Contaminations in Urban Soils, Urban Road Dusts and Agricultural Soils from China," Microchemical Journal, Vol. 94, No. 2, 2010, pp. 99-107. doi:10.1016/j.microc.2009.09.014

[6] F. L. Fu and Q. Wang, "Removal of Heavy Metal Ions from Wastewaters: A Review," Journal of Environmental Management, Vol. 92, No. 3, 2011, pp. 407-418. doi:10.1016/j.jenvman.2010.11.011

[7] WHO, "Guidelines for Drinking Water Quality, Chemical Facts Sheets," 2003. www.who.int

[8] S. Mohan and G. Sreelakshmi, "Fixed Bed Column Study for Heavy Metal Removal Using Phosphate Treated Rice Husk," Journal of Hazardous Materials, Vol. 153, No. 12, 2008, pp. 75-82. doi:10.1016/j.jhazmat.2007.08.021

[9] M. Schaefer and G. D. Gitlin, "Genetic Disorders of Membrane Transport. IV. Wilson's Disease and Menkes Disease," The American Journal of Physiology, Vol. 276, No. 2, 1999, pp. 311-314.

[10] S. S. Saei-Dehkordi and A. A. Fallah, "Determination of Copper, Lead, Cadmium and Zinc Content in Commercially Valuable Fish Species from the Persian Gulf Using Derivative Potentiometric Stripping Analysis," Microchemical Journal, Vol. 98, No. 1, 2011, pp. 156-162. doi:10.1016/j.microc.2011.01.001

[11] J. C. Cypriano, M. A. C. Matos and R. C. Matos, "Ultrasound-Assisted Treatment of Palm Oil Samples for the Determination of Copper and Lead by Stripping Chronopotentiometry," Microchemical Journal, Vol. 90, No. 1, 2008, pp. 26-30. doi:10.1016/j.microc.2008.03.001

[12] M. Mazloum-Ardakani, Z. Akrami, H. Kazemian and H. R. Zare, "Preconcentration and Electroanalysis of Copper at Zeoilte Modified Carbon Paste Electrode," Interna- tional Journal of Electrochemical Science, Vol. 4, No. 2, 2009, pp. 308-319.

[13] A. Tobiasz, S. Walas, L. Landowska and J. Konefał-Goral, "Improvement of Copper FAAS Determination Conditions via Preconcentration Procedure with the Use of Salicylaldoxime Complex Trapped in Polymer Matrix," Talanta, Vol. 96, No. 4, 2012, pp. 82-88. doi:10.1016/j.talanta.2012.02.005

[14] P. C. Bull and D. W. Cox, "Wilson Disease and Menkes Disease: New Handles on Heavy-Metal Transport," Trends in Genetics, Vol. 10, No. 7, 1994, pp. 246-252. doi:10.1016/0168-9525(94)90172-4

[15] B. Halford, "Ladder Polyethers in a Snap," Chemical \& Engineering News, Vol. 84, No. 3, 2006, pp. 35-36.

[16] S. Morrissey, "Reclassifying Nanosilver," Chemical \& Engineering News, Vol. 84, No. 49, 2006, pp. 14-20.

[17] D. Brandt, B. Park, M. Hoang and H. T. Jacobe, "Argyria Secondary to Ingestion of Homemade Silver Solution," Journal of the American Academy of Dermatology, Vol. 53, No. 2, 2005, pp. S105-S107. doi:10.1016/j.jaad.2004.09.026

[18] A. M. Donia, A. A. Atia and K. Z. Elwakeel, "Recovery of Gold(III) and Silver(I) on a Chemically Modified Chitosan with Magnetic Properties," Hydrometallurgy, Vol. 87, No. 3-4, 2007, pp. 197-206. doi:10.1016/j.hydromet.2007.03.007

[19] X. Wang, L. Zhang, C. Ma, R. Song, H. Hou and D. Li, "Enrichment and Separation of Silver from Waste Solutions by Metal Ion Imprinted Membrane," Hydrometallurgy, Vol. 100, No. 1-2, 2009, pp. 82-86. doi:10.1016/j.hydromet.2009.10.006

[20] G. Yang, W. Fen, C. Lei, W. Xiao and H. Sun, "Study on Solid Phase Extraction and Graphite Furnace Atomic Absorption Spectrometry for the Determination of Nickel, Silver, Cobalt, Copper, Cadmium and Lead with MCI GEL CHP 20Y as Sorbent," Journal of Hazardous Materials, Vol. 162, No. 1, 2009, pp. 44-49. doi:10.1016/j.jhazmat.2008.05.007

[21] U. Divrikli, A. A. Kartal, M. Soylak and L. Elci, "Preconcentration of $\mathrm{Pb}(\mathrm{II}), \mathrm{Cr}(\mathrm{III}), \mathrm{Cu}(\mathrm{II}), \mathrm{Ni}(\mathrm{II})$ and $\mathrm{Cd}(\mathrm{II})$ Ions in Environmental Samples by Membrane Filtration Prior to Their Flame Atomic Absorption Spectrometric Determinations," Journal of Hazardous Materials, Vol. 145, No. 3, 2007, pp. 459-464. doi:10.1016/j.jhazmat.2006.11.040

[22] I. Narin, M. Soylak, K. Kayakirilmaz, L. Elci and M. Dogan, "Preparation of a Chelating Resin by Immobilizing 1-(2-pyridylazo) 2-naphtol on Amberlite XAD-16 and Its Application of Solid Phase Extraction of Ni(II), Cd(II), $\mathrm{Co}(\mathrm{II}), \mathrm{Cu}(\mathrm{II}), \mathrm{Pb}(\mathrm{II})$, and $\mathrm{Cr}(\mathrm{III})$ in Natural Water Samples," Analytical Letters, Vol. 36, No. 3, 2003, pp. 641-658.

[23] D. L. Giokas, E. K. Paleologos and M. I. Karayannis, "Single-Sample Cloud Point Determination of Iron, Cobalt and Nickel by Flow Injection Analysis Flame Atomic Absorption Spectrometry-Application to Real Samples and Certified Reference Materials," Journal of Analytical Atomic Spectrometry, Vol. 16, No. 5, 2001, pp. 521-526. doi:10.1039/b010055m

[24] Q. F. Hu, G. Y. Yang, J. H. Yang and J. Y. Yin, "Study on Determination of Iron, Cobalt, Nickel, Copper, Zinc 
and Manganese in Drinking Water by Solid-Phase Extraction and RP-HPLC with 2-(2-Quinolinylazo)-5-Diethylaminophenol as Precolumn Derivatizing Reagent," Journal of Environmental Monitoring, Vol. 4, No. 6, 2002, pp. 956-959. doi:10.1039/b204874b

[25] P. Kuban, R. Guchardi and P. C. Hauser, "Trace-Metal Analysis with Separation Methods," TrAC Trends in Analytical Chemistry, Vol. 24, No. 3, 2005, pp. 192-198.

[26] V. Camel, "Solid Phase Extraction of Trace Elements," Spectrochimica Acta Part B: Atomic Spectroscopy, Vol. 58, No. 7, 2003, pp. 1177-1233. doi:10.1016/S0584-8547(03)00072-7

[27] Q. F. Hu, G. Y. Yang, Y. Y. Zhao and J. Y. Yin, "Determination of Copper, Nickel, Cobalt, Silver, Lead, Cadmium and Mercury Ions in Water by Solid Phase Extraction and the RP-HPLC with UV-Vis Detection," Analytical Bioanalytical Chemistry, Vol. 375, No. 6, 2003, pp. 831-837.

[28] K. Pyrzynska, "Application of Carbon Sorbents for the Concentration and Separation of Metal Ions," Analytical Sciences, Vol. 23, No. 6, 2007, pp. 631-637. doi:10.2116/analsci.23.631

[29] Q. F. Hu, X. J. Yang, Z. J. Huang, J. Chen and G. Y. Yang, "Simultaneous Determination of Palladium, Platinum, Rhodium and Gold by On-Line Solid Phase Extraction and High Performance Liquid Chromatography with 5-(2-Hydroxy-5-Nitrophenylazo) Thiorhodanine as PreColumn Derivatization Regents," Journal of Chromatography A, Vol. 1094, No. 1-2, 2005, pp. 77-82. doi:10.1016/i.chroma.2005.07.090

[30] A. A. Ensafi, T. Khayamian and M. H. Karbasi, "On-Line Preconcentration System for Lead(II) Determination in Wastewater by Atomic Absorption Spectrometry Using Active Carbon Loaded with Pyrogallol Red," Analytical Sciences, Vol. 19, No. 6, 2003, pp. 953-956. doi:10.2116/analsci.19.953

[31] M. K. Rofouei, M. Payehghadr, M. Shamsipur and A. Ahmadalinezhad, "Solid Phase Extraction of Ultra Traces Silver(I) Using Octadecyl Silica Membrane Disks Modified by 1,3-Bis(2-Cyanobenzene) Triazene (CBT) Ligand Prior to Determination by Flame Atomic Absorption," Journal of Hazardous Materials, Vol. 168, 2009, pp. 1184-1187. doi:10.1016/j.jhazmat.2009.02.165

[32] B. B. Johnson, "Effect of pH, Temperature, and Concentration on the Adsorption of Cadmium on Goethite," Environmental Science \& Technology, Vol. 24, No. 1, 1990, pp. 112-118. doi:10.1021/es00071a014

[33] X. C. Yu, P. F. Zhu, Y. X. Chen, J. Wang and Z. F. An, "Study on Preparation of Modified Nano- $\mathrm{TiO}_{2}$ and Its Application in Photocatalytic Treatment Wastewater Containing $\mathrm{Cd}^{2+}$," Advanced Materials Research, Vol. 347353, No. 8, 2012, pp. 733-737. doi:10.4028/www.scientific.net/AMR.347-353.733

[34] J. Hu, G. Chen and I. M. C. Lo, "Selective Removal of Heavy Metals from Industrial Wastewater Using Maghemite Nanoparticle: Performance and Mechanisms," Journal of Environmental Engineering, Vol. 132, No. 7, 2006, pp. 709-715. doi:10.1061/(ASCE)0733-9372(2006)132:7(709)

[35] H. J. Shipley, S. Yean, A. T. Kan and M. B. Tomson,
"Adsorption of Arsenic to Magnetite Nanoparticles: Effect of Particle Concentration, $\mathrm{pH}$, Ionic Strength, and Temperature," Environmental Toxicology and Chemistry, Vol. 28, No. 3, 2009, pp. 509-515. doi:10.1897/08-155.1

[36] K. Engates and H. Shipley, "Adsorption of $\mathrm{Pb}, \mathrm{Cd}, \mathrm{Cu}$, $\mathrm{Zn}$, and Ni to Titanium Dioxide Nanoparticles: Effect of Particle Size, Solid Concentration, and Exhaustion," Environmental Science and Pollution Research, Vol. 18, No. 3, 2011, pp. 386-395. doi:10.1007/s11356-010-0382-3

[37] T. Kasuga, "Formation of Titanium Oxide Nanotubes Using Chemical Treatments and Their Characteristic Properties," Thin Solid Films, Vol. 496, No. 1, 2006, pp. 141-145. doi:10.1016/j.tsf.2005.08.341

[38] A. H. Liu, M. D. Wie, I. Honma and H. S. Zhou, "Direct Electrochemistry of Myoglobin in Titanate Nanotubes Film," Analytical Chemistry, Vol. 77, No. 24, 2005, pp. 8068-8074. doi:10.1021/ac051640t

[39] J. Nawrocki, C. Dunlap, A. McCormick and P. W. Carr, "Chromatography Using Ultra-Stable Metal Oxide-Based Stationary Phases for HPLC," Journal of Chromatography A, Vol. 1028, No. 1, 2004, pp. 1-30. doi:10.1016/j.chroma.2003.11.052

[40] E. Vassileva, I. Proinova and K. Hadjiivanov, "SolidPhase Extraction of Heavy Metal Ions on a High Surface Area Titanium Dioxide (Anatase)," Analyst, Vol. 121, No. 5, 1996, pp. 607-612. doi:10.1039/an9962100607

[41] V. Camel, "Solid Phase Extraction of Trace Elements," Spectrochimica Acta Part B: Atomic Spectroscopy, Vol. 58, No. 7, 2003, pp. 1177-1233. doi:10.1016/S0584-8547(03)00072-7

[42] L. Zhang, D. Ishi, K. Shitou, Y. Morita and A. Isozaki, "Simultaneous Multi-Element Analysis of Total As, Se and $\mathrm{Sb}$ on Titanium Dioxide by Slurry Sampling - Graphite Furnace Atomic Absorption Spectrometry," Talanta, Vol. 68, No. 2, 2005, pp. 336-342. doi:10.1016/j.talanta.2005.08.072

[43] M. H. Pinkse, P. M. Uitto, M. J. Hilhorst, B. Ooms and A. J. R. Heck, "Selective Isolation at the Femtomole Level of Phosphopeptides from Proteolytic Digests Using 2DNanoLCESI-MS/MS and Titanium Oxide Precolumns," Analytical Chemistry, Vol. 76, No. 14, 2004, pp. 39353943. doi:10.1021/ac0498617

[44] B. B. Kefi, L. L. E. Atrache, H. Kochkar and A. Ghorbel, " $\mathrm{TiO}_{2}$ Nanotubes as Solid-Phase Extraction Adsorbent for the Determination of Polycyclic Aromatic Hydrocarbons in Environmental Water Samples," Journal of Environmental Sciences, Vol. 23, No. 5, 2011, pp. 860-867. doi:10.1016/S1001-0742(10)60481-0

[45] K. Mehrani, A. Mehrani, M. M. Amini, O. Sadeghi and N. Tavassoli, "Dipyridylamine-Modified Nanoporous Silicas as New Sorbents for the Separation and Pre-Concentration of Palladium," Microchimica Acta, Vol. 173, No. 3-4, 2011, pp. 521-527. doi:10.1007/s00604-011-0590-7

[46] A. Bagheri, M. Behbahani, M. M. Amini, O. Sadeghi, M. Taghizade, L. Baghayi and M. Salarian, "Simultaneous Separation and Determination of Trace Amounts of Cd(II) and $\mathrm{Cu}(\mathrm{II})$ in Environmental Samples Using Novel Diphenylcarbazide Modified Nanoporous Silica," Talanta, Vol. 89, No. 3, 2012, pp. 455-461. doi:10.1016/j.talanta.2011.12.062 